\title{
A Comparison Study for Chloride-Binding Capacity between Alkali-Activated Fly Ash and Slag in the Use of Seawater
}

\author{
Yubin Jun ${ }^{1}$, Seyoon Yoon ${ }^{2, *}$ (D) and Jae Eun $\mathrm{Oh}^{1, *}$ \\ 1 School of Urban and Environmental Engineering, Ulsan National Institute of Science and \\ Technology (UNIST), Ulsan 44919, Korea; ssjun97@gmail.com \\ 2 Department of Civil Engineering, Kyonggi University, Suwon 16227, Korea \\ * Correspondence: yoonseyoon@kyonggi.ac.kr (S.Y.); ohjaeeun@unist.ac.kr (J.E.O.); \\ Tel.: +82-31-249-9711 (S.Y.); +82-52-217-2815 (J.E.O.)
}

Received: 25 August 2017; Accepted: 19 September 2017; Published: 22 September 2017

Featured Application: The results of this study can be applied to the production of cementless concrete using seawater.

\begin{abstract}
This study aimed to investigate the chloride-binding capacity of alkali-activated fly ash (denoted as FSW) and slag (denoted as SSW) samples and their synthesized Cl-bearing phases, which are capable of binding and immobilizing chloride when seawater is used as the mixing water. This study also examined the progressive changes in the pore structures of the FSW and SSW samples over time. The results show that the SSW sample is significantly more effective in the uptake of chloride ions compared to the FSW sample at 28 days of curing. While the FSW sample forms $\mathrm{Cl}$-bearing zeolites (Cl-chabazite and $\mathrm{Cl}$-sodalite) (possibly with similar types of geopolymeric gels), the SSW sample synthesizes Cl-bearing, layered double hydroxides (LDH) (Cl-hydrocalumite and Cl-hydrotalcite). Although both samples involve Cl-binding phases, the FSW sample is likely to be less efficient because it largely produces zeolites (or similar geopolymeric gels) with no Cl-binding capability (i.e., zeolites $\mathrm{X}$ and $\mathrm{Y}$ ). Meanwhile, the SSW sample produces $\mathrm{Cl}$-bearing $\mathrm{LDH}$ phases as well as C-S-H(I), which can physically adsorb chloride. The SSW sample exhibits both pore-size refinement and porosity reduction over time, while the FSW sample only exhibits pore-size refinement. Therefore, the SSW system is more advantageous in the use of seawater because it more effectively prevents $\mathrm{Cl}$ ingression due to greater impermeability.
\end{abstract}

Keywords: alkali-activated binders; fly ash; ground-granulated blast furnace slag (GGBFS); seawater; chloride; zeolite; layered double hydroxide

\section{Introduction}

The global cement and concrete industry is facing environmental challenges. First, the calcination process for cement clinkers releases $0.8-1.0$ tons of carbon dioxide to produce one ton of ordinary portland cement (OPC) $[1,2]$. As a result, the total $\mathrm{CO}_{2}$ emission from worldwide OPC production is equivalent to $6-8 \%$ of global $\mathrm{CO}_{2}$ emissions [3]. Furthermore, the production of OPC concrete consumes a significant quantity of fresh water, more specifically one billion tons of fresh water per year [4]. Currently, water shortages are already serious problems in the Middle Eastern and North African nations, which have already imported a huge volume of fresh water, such as Saudi Arabia, United Arab Emirates, Bahrain, Qatar, Kuwait, Yemen, Libya, Jordan, and Israel [5]. This water shortage may become a vital challenge to other nations in the near future due to climate change [6]. Finally, existing concrete structures suffer durability issues due to chemical deteriorations, such as chloride attacks, corrosion, and 
sulfate attacks [2,7]. Therefore, the enhancement of concrete durability will help to improve environmental sustainability by reducing unnecessary resource consumption for maintenance.

New eco-efficient binders, such as calcium sulfoaluminate cements [8], super-sulfate cements [9], calcium aluminate cements [10], and alkali-activated binders [11,12], have been introduced and developed to address the significant $\mathrm{CO}_{2}$ emissions from OPC production. The alkali-activated binder is likely to be a high-profile candidate to replace OPC due to its significantly low production of $\mathrm{CO}_{2}$ and comparable performances of strength and durability to OPC [13].

To reduce the current level of fresh water consumption for OPC concrete production, many earlier studies have explored the possible use of seawater in the concrete's production $[14,15]$. However, the presence of chloride from seawater in concrete likely induces serious corrosion of embedded steel bars [2]. In the previous literature, alkali-activated binders showed better durability against a saline environment compared to OPC pastes [16]. Thus, in unavoidable situations leading to the use of seawater, the application of alkali-activated binders would be a better choice than OPC in terms of chloride-induced durability problems. In addition to using seawater, for concrete structures exposed to marine environments, alkali-activated binders could also provide a longer service life of concrete structures with better durability against seawater [17]. Consequently, alkali-activated binders may play important roles in addressing the aforementioned environmental concerns (i.e., $\mathrm{CO}_{2}$ emissions, water shortages, and durability). Therefore, it is important to understand the interactions between seawater and alkali-activated binders.

Among the alkali-activated binders, two representatives are alkali-activated fly ash (also called fly ash-based geopolymer) and alkali-activated slag. In the previous literature, Arbi et al. well-reviewed the recent research on the chloride resistance of alkali-activated fly ash/slag systems [18], and showed that most studies on the chloride resistance of alkali-activated binders were based on measurements of rapid chloride permeability tests (RCPT) and non-steady-state migration (NSSM). Few studies have been conducted on $\mathrm{Cl}$-bearing phases, which are capable of binding and immobilizing chloride, and stable phases when seawater is used as the mixing water in alkali-activated binders, while Friedel's salt and Kuzel's salt in OPC pastes have been studied actively $[19,20]$. Regarding the stable phases in alkali-activated fly ash with seawater, Belviso et al. attempted to synthesize zeolite from alkali-activated fly ash using seawater at various temperatures, and they found zeolite X, zeolite ZK-5, and sodalite in the samples [21]. Regarding Cl-bearing phases in alkali-activated slag, Khan et al. recently reported a formation of Friedel's salt in $5 \mathrm{M} \mathrm{NaOH}$-activated slag with $2.47 \% \mathrm{NaCl}$ solution [22]. Aside from these two studies, no study has compared alkali-activated slag and fly ash in terms of their Cl-binding capacities and their Cl-bearing phases.

Therefore, the present study aimed to fill the research gap by comparing the Cl-binding capabilities and Cl-bearing phases between alkali-activated slag and fly ash systems when seawater was used as a mixing water. The progressive change in pore structure over time, which is related to impermeability to $\mathrm{Cl}$ ingression, was also tested. A mixed solution of $\mathrm{NaOH}, \mathrm{Na}_{2} \mathrm{SiO}_{3}$, and seawater was used as the main activating solution in this study because $\mathrm{NaOH}$ and $\mathrm{Na}_{2} \mathrm{SiO}_{3}$ have been often used as alkaline activators in alkali-activated binders [23]. Free and bound chloride contents were obtained by measuring acid-soluble and water-soluble chloride contents. Cl-bearing phases were identified through X-ray diffraction (XRD). Finally, mercury intrusion porosimetry (MIP) was conducted to observe changes in the pore structures. The results provide a better understanding of the Cl-bearing phases and pore structures in alkali-activated binders.

\section{Experimental}

\subsection{Materials}

Fly ash (Class F according to ASTM C 618 [24]) and ground-granulated blast furnace slag (GGBFS) were obtained. Table 1 lists the chemical compositions of the raw materials measured through X-ray fluorescence (XRF), and Figure 1 presents the XRD patterns of fly ash and GGBFS with the reference 
peaks of the identified phases. Table 1 and Figure 1 show that both raw materials are general fly ash and GGBFS [25-27].

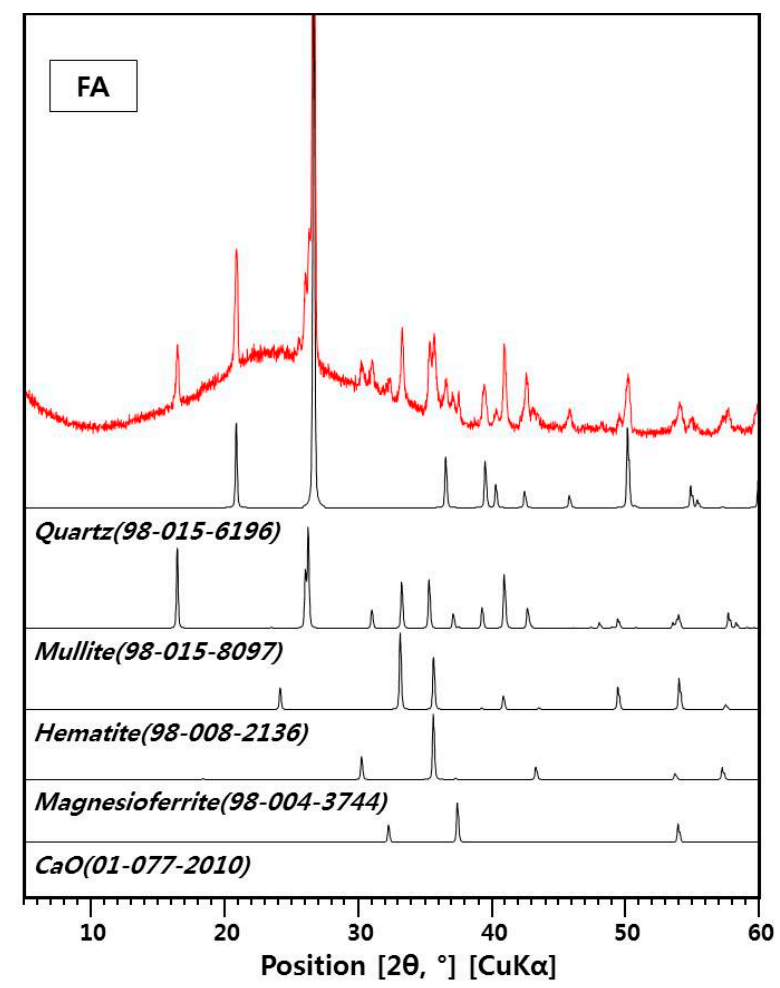

(a)

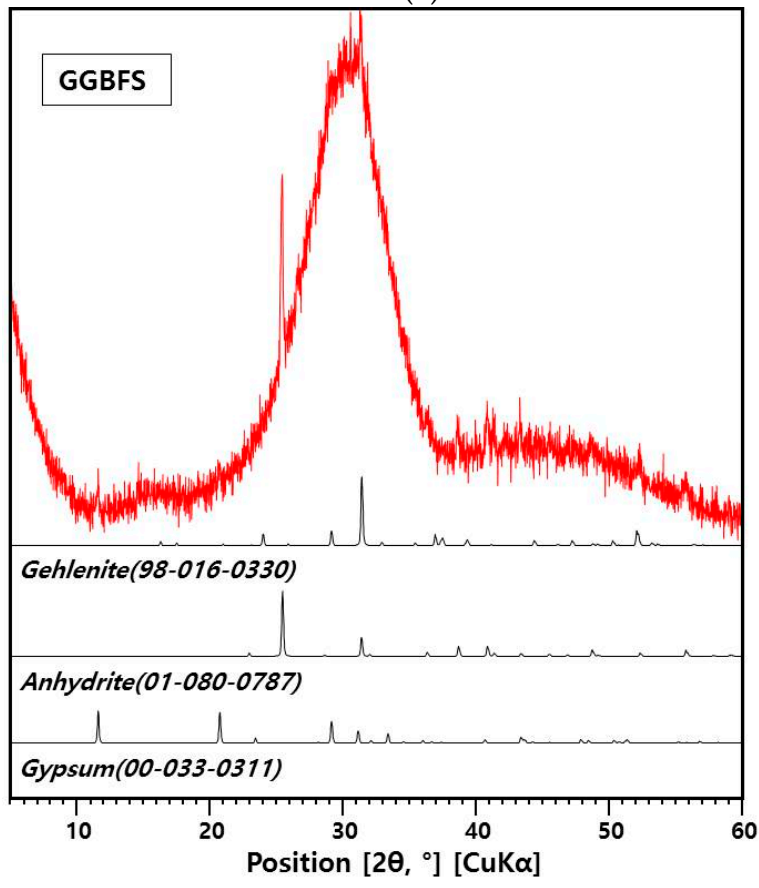

(b)

Figure 1. XRD patterns of (a) fly ash (FA) and (b) ground-granulated blast furnace slag (GGBFS).

A mixture of $\mathrm{NaOH}$ and $\mathrm{Na}_{2} \mathrm{SiO}_{3}$ (reagent grade, $10.6 \% \mathrm{Na}_{2} \mathrm{O}, 26.5 \% \mathrm{SiO}_{2}, 62.9 \% \mathrm{H}_{2} \mathrm{O}$, Sigma-Aldrich, St. Louis, MO, USA) was used as the alkaline activator. Ten moles (10 M) NaOH solution was made from $\mathrm{NaOH}$ pallet (reagent grade, $\geq 98 \%$ purity) and the seawater. 
The seawater was collected from Songdo in South Korea ( $35^{\circ} 04^{\prime} 32^{\prime \prime}$ north, $129^{\circ} 01^{\prime} 01^{\prime \prime}$ east). The $\mathrm{pH}$ value of the seawater was 8.4, and it contained several types of cations and anions. The cations $\left(\mathrm{Ca}^{2+}, \mathrm{K}^{+}, \mathrm{Mg}^{2+}\right.$, and $\left.\mathrm{Na}^{+}\right)$were measured using inductively coupled plasma atomic emission spectroscopy (ICP-AES), and the anions $\left(\mathrm{Cl}^{-}\right.$and $\mathrm{SO}_{4}{ }^{2-}$ ) were quantified using ion chromatography (IC). Table 2 lists the chemical composition of the collected seawater and indicates that the used seawater had a typical chemical composition of seawater [28].

Table 1. Chemical compositions of fly ash and ground-granulated blast furnace slag (GGBFS) used in this study.

\begin{tabular}{|c|c|c|c|}
\hline \multicolumn{2}{|c|}{ FA } & \multicolumn{2}{|c|}{ GGBFS } \\
\hline Oxide & wt $\%$ & Oxide & wt $\%$ \\
\hline $\mathrm{SiO}_{2}$ & 51.29 & $\mathrm{CaO}$ & 47.42 \\
\hline $\mathrm{Al}_{2} \mathrm{O}_{3}$ & 22.16 & $\mathrm{SiO}_{2}$ & 31.97 \\
\hline $\mathrm{Fe}_{2} \mathrm{O}_{3}$ & 9.71 & $\mathrm{Al}_{2} \mathrm{O}_{3}$ & 12.51 \\
\hline $\mathrm{CaO}$ & 6.44 & $\mathrm{MgO}$ & 3.21 \\
\hline $\mathrm{K}_{2} \mathrm{O}$ & 1.87 & $\mathrm{SO}_{3}$ & 2.51 \\
\hline $\mathrm{Na}_{2} \mathrm{O}$ & 1.73 & $\mathrm{TiO}_{2}$ & 0.66 \\
\hline $\mathrm{MgO}$ & 1.72 & $\mathrm{~K}_{2} \mathrm{O}$ & 0.53 \\
\hline $\mathrm{TiO}_{2}$ & 1.36 & $\mathrm{Fe}_{2} \mathrm{O}_{3}$ & 0.41 \\
\hline $\mathrm{P}_{2} \mathrm{O}_{5}$ & 1.29 & $\mathrm{MnO}$ & 0.34 \\
\hline $\mathrm{SO}_{3}$ & 1.24 & $\mathrm{Na}_{2} \mathrm{O}$ & 0.21 \\
\hline $\mathrm{SrO}$ & 0.37 & $\mathrm{SrO}$ & 0.08 \\
\hline $\mathrm{MoO}_{3}$ & 0.34 & $\mathrm{BaO}$ & 0.07 \\
\hline $\mathrm{BaO}$ & 0.23 & $\mathrm{ZrO}_{2}$ & 0.05 \\
\hline $\mathrm{MnO}$ & 0.08 & $\mathrm{Cl}$ & 0.02 \\
\hline $\mathrm{V}_{2} \mathrm{O}_{5}$ & 0.05 & - & - \\
\hline $\mathrm{ZnO}$ & 0.02 & - & - \\
\hline $\mathrm{Cr}_{2} \mathrm{O}_{3}$ & 0.02 & - & - \\
\hline $\mathrm{CuO}$ & 0.02 & - & - \\
\hline $\mathrm{NiO}$ & 0.02 & - & - \\
\hline $\mathrm{Cl}$ & 0.01 & - & - \\
\hline
\end{tabular}

Table 2. Ionic concentrations of seawater (ppm).

\begin{tabular}{cccccc}
\hline $\mathbf{C a}^{2+}$ & $\mathbf{K}^{+}$ & $\mathbf{M g}^{2+}$ & $\mathbf{N a}^{+}$ & $\mathbf{C l}^{-}$ & $\mathbf{S O}_{4}{ }^{2-}$ \\
\hline 480 & 300 & 1200 & 10,000 & 15,000 & 2600 \\
\hline
\end{tabular}

\subsection{Sample Preparation}

Fly ash and GGBFS were independently mixed with the alkaline activator. $\mathrm{NaOH}$ solution was prepared by dissolving $\mathrm{NaOH}$ pellets in seawater to $10 \mathrm{~mol} / \mathrm{L}$, and then cooling to room temperature. $\mathrm{Na}_{2} \mathrm{SiO}_{3}$ solution was mixed with $\mathrm{NaOH}$ solution with a weight ratio of 3:7 [29,30]. The weight ratio of the activator ( $10 \mathrm{M} \mathrm{NaOH}$ in seawater $+\mathrm{Na}_{2} \mathrm{SiO}_{3}$ solution) to the binder (fly ash or GGBFS) was fixed at 0.45 . Table 3 summarizes the detailed mixture proportion of the samples. In the present study, the sample of alkali-activated fly ash with seawater (fly ash with seawater) will be denoted FSW and that of alkali-activated GGBFS (GGBFS with seawater) will be SSW in the following sections. After mixing, the pastes were cast into $50 \times 50 \times 50 \mathrm{~mm}$ cubic molds for strength and XRD tests, and $\Phi 25.4 \times 25.4 \mathrm{~mm}$ cylinder molds for MIP. The samples were cured at a temperature of $60^{\circ} \mathrm{C}$ and a relative humidity of $99 \%$. The compressive strengths of the hardened samples were measured at the age of 7 and 28 days of curing. The loading rate was $0.4 \mathrm{~mm} / \mathrm{min}$. Fractured specimens after a compressive strength test were finely powdered for the XRD and chloride tests. At the age of 7 and 28 days of curing, cross sections with a thickness of $2 \mathrm{~mm}$ along the length of the hardened cylindrical samples were prepared for MIP analysis using a precision saw. The specimens were immersed in isopropanol to stop further hydration. After vacuum drying, the specimens were examined by MIP. 
Table 3. Mix proportions of samples.

\begin{tabular}{|c|c|c|c|c|}
\hline \multirow{2}{*}{$\begin{array}{c}\text { Binder (g) } \\
\text { (GGBFS or Fly Ash) }\end{array}$} & \multicolumn{2}{|c|}{ Activator (g) } & \multirow{2}{*}{$\begin{array}{c}\text { Activator/ } \\
\text { Binder Ratio }\end{array}$} & \multirow{2}{*}{ Curing Temp $\left({ }^{\circ} \mathrm{C}\right)$} \\
\hline & $10 \mathrm{M} \mathrm{NaOH}$ in Seawater & $\mathrm{Na}_{2} \mathrm{SiO}_{3}$ Solution & & \\
\hline $\begin{array}{c}1600 \\
\left(1240 \text { or } 1130 \mathrm{~kg} / \mathrm{m}^{3}\right)\end{array}$ & 504 & 216 & 0.45 & 60 \\
\hline
\end{tabular}

\subsection{Test Methods}

\subsubsection{Compressive Strength Test}

The compressive strengths of the hardened samples were measured at 7 and 28 days of curing. Figure 2 presents the test results as an average of the triplicate samples. Since the present study focused on the chloride-binding capabilities of the samples, the results of the strength tests are presented in this section. The strength development of the samples similarly followed the alkali-activated binders reported in previous studies $[11-13,17,23,31]$. The specimens that fractured after the compressive strength tests were finely ground for chloride content tests and XRD.

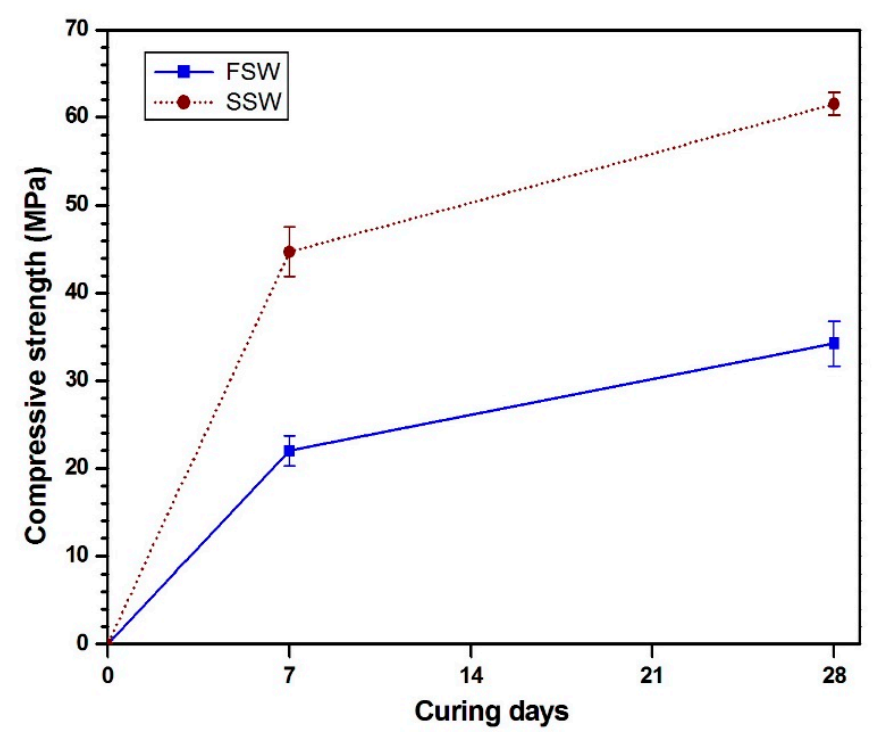

Figure 2. Compressive strengths of prepared samples of this study at 7 and 28 days. FSW: alkali-activated fly ash; SSW: alkali-activated GGBFS.

\subsubsection{Measurement of Free and Bound Chloride Contents}

Regardless of whether chloride ions originate from internal or external sources, chloride ions can be either free or bound chloride contents. Free chloride ions are presented in a free form in a pore solution, indicating that they can freely move through the pore solution in concrete, while bound chloride ions are immobilized chloride ions. The bound chloride contents can be calculated by subtracting a free chloride content from a total chloride content [32-34]. The free chloride and total chloride contents can be respectively measured from water-soluble (see ASTM C 1218 [35]) and acid-soluble (see ASTM C1152 [36]) chloride contents [35,36]. Even though the acid-soluble chloride contents depend on the solubility of $\mathrm{Cl}$-bearing phases, ASTM C 1152 is the only well-established test method to measure the total chloride contents of cement-based samples.

\subsubsection{XRD and MIP Tests}

XRD was performed using a high-power X-ray diffractometer (D/Max2500V/PC, Rigaku, Tokyo, Japan) with a $\mathrm{Cu} \mathrm{K} \alpha$ radiation, at a scanning rate of $1^{\circ} / \mathrm{min}$ from 5 to $60^{\circ} 2 \theta$. The XRD data was 
analyzed using X'pert HighScore Plus software [37] with the International Centre for Diffraction Data (ICDD) PDF-2 database [38].

At 7 and 28 days of curing, MIP samples with a thickness of $2 \mathrm{~mm}$ were prepared using a precision saw. The specimens were immersed in isopropanol to stop further hydration until the MIP tests was conducted. After vacuum drying of the samples, MIP (AutoPore IV 9500, Micromeritics, Norcross, GA, USA) was performed.

\section{Results and Discussion}

\subsection{Free and Bound $\mathrm{Cl}$ Contents}

Figure 3 shows the measured contents of free and bound chloride in the FSW and SSW samples. In this case, the bound chloride content of the FSW sample increased from $59 \%$ to $69 \%$, while that of the SSW sample did from $42 \%$ to $91 \%$ between 7 and 28 days. Although SSW did not show any noticeable advantage in immobilizing free chloride, compared to FSW, at 7 days, it clearly did at 28 days.

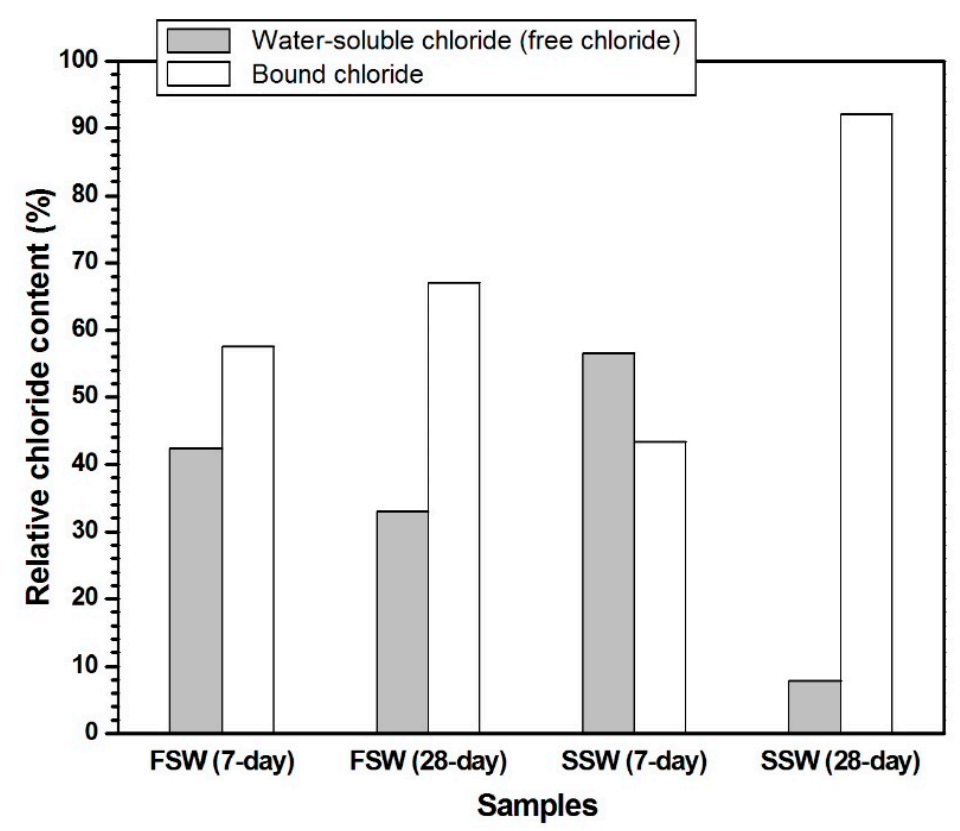

Figure 3. Relative \% contents of free and bound chloride in the FSW and SSW samples at 7 and 28 days.

\subsection{XRD Results}

Figure 4 presents the XRD results of the hardened FSW and SSW samples and identified phases at 7 and 28 days.

Before discussing the phase identifications in detail (see Sections 3.2.1 and 3.2.2), it is worth noting that two major binding mechanisms for chloride in hydrated portland cements are known: (1) the formation of $\mathrm{Cl}$-bearing $\mathrm{Al}_{2} \mathrm{O}_{3}-\mathrm{Fe}_{2} \mathrm{O}_{3}$-mono (AFm) phases, such as Friedel's salt and Kuzel's salt, and (2) surface-sorption by calcium silicate hydrate (C-S-H) [39]. Among these two mechanisms, Hosokawa reported that the chemical binding by AFm phases more greatly contributed to chloride uptake than the physical binding by C-S-H surfaces [40], indicating that the chemical binding by Cl-bearing phases would be an effective way to increase the $\mathrm{Cl}$-binding capacity of hydrated portland cements. Therefore, similarly, the chloride-binding capabilities of the FSW and SSW samples would be importantly affected by the formation of $\mathrm{Cl}$-bearing phases. 


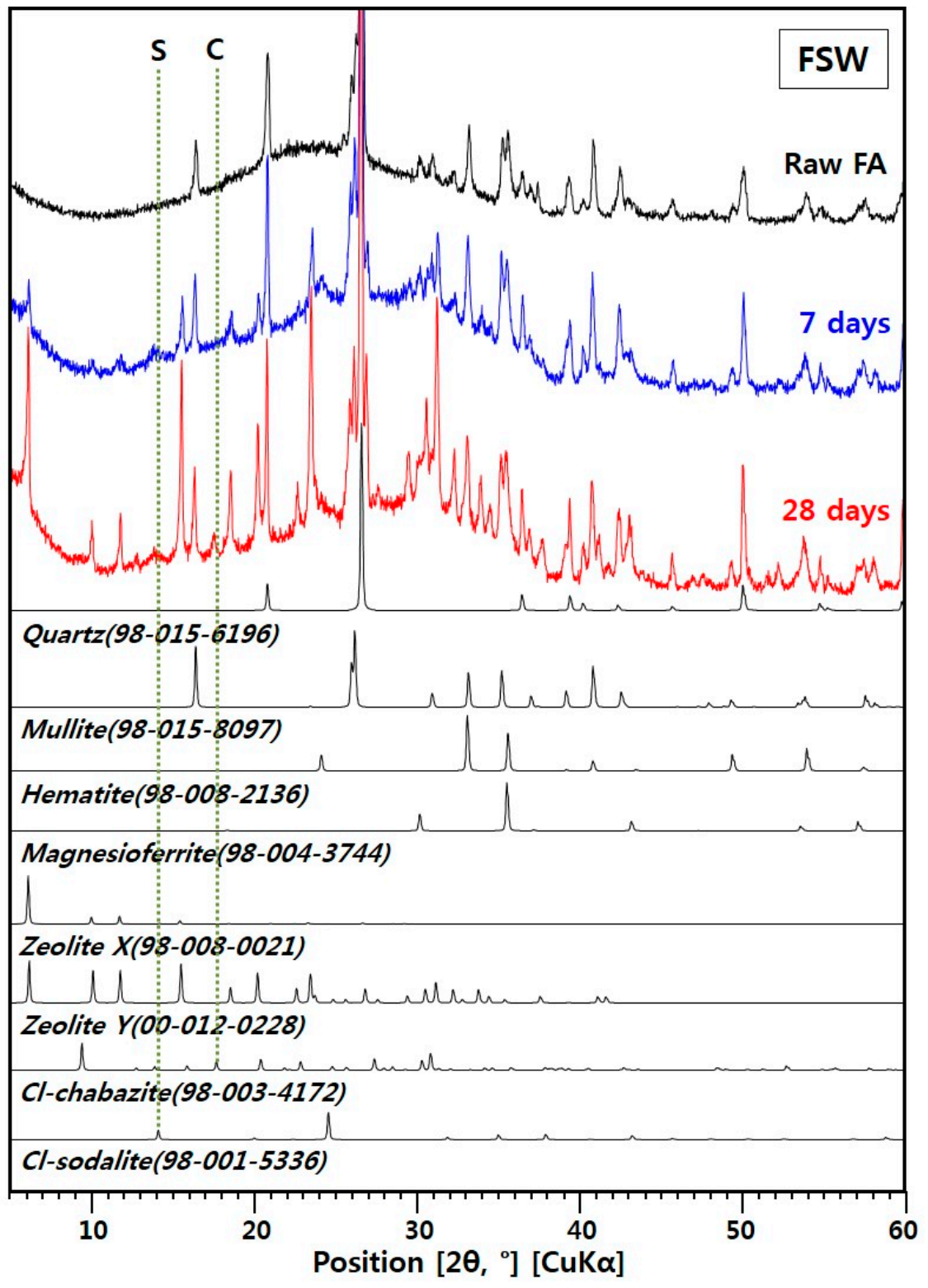

(a)

Figure 4. Cont. 


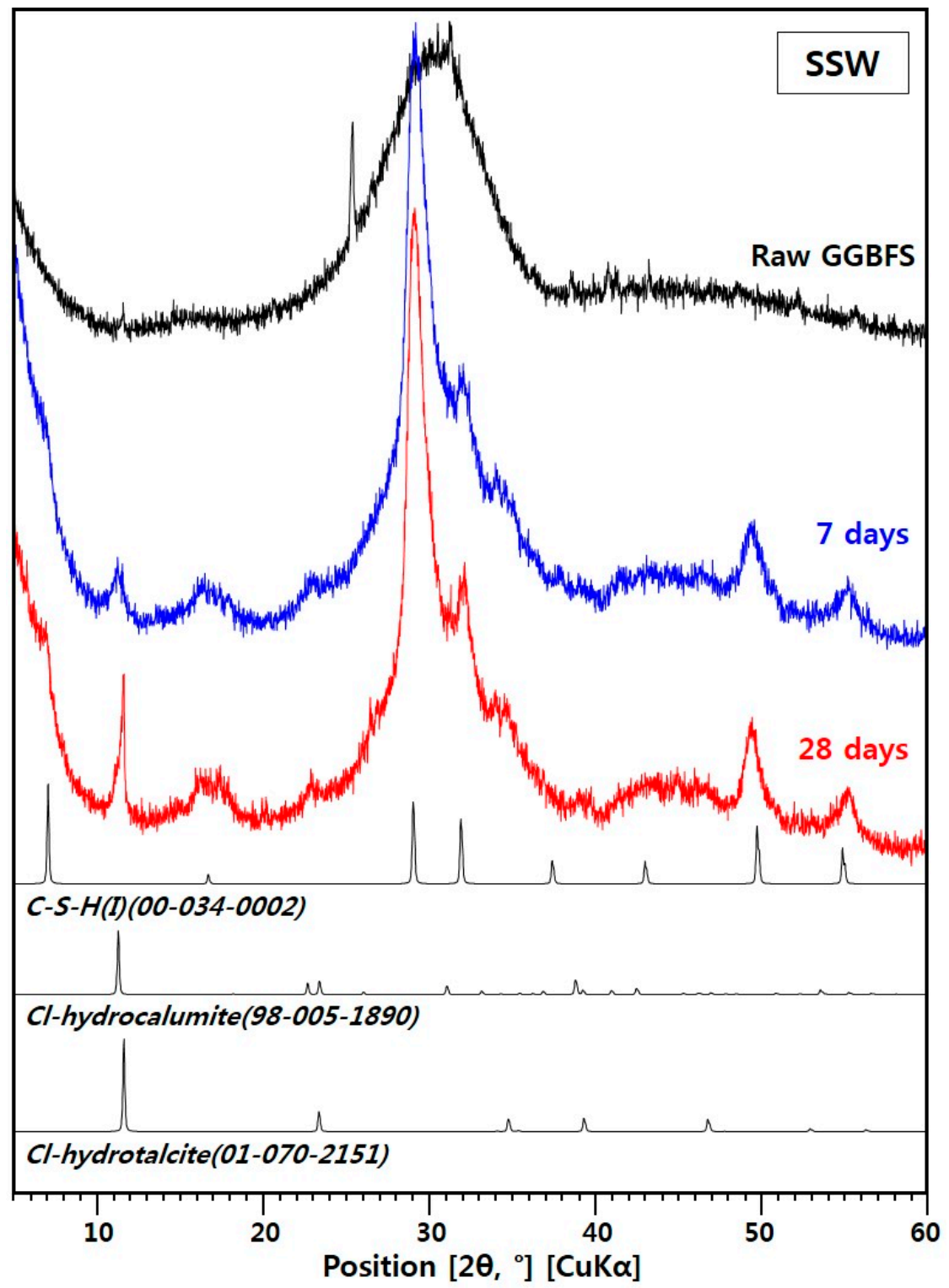

(b)

Figure 4. XRD patterns of (a) raw fly ash and FSW, and (b) raw GGBFS and SSW samples at 7 and 28 days; dashed line ' $\mathrm{S}$ ' is the location of the $\left(\begin{array}{lll}0 & 1 & 1\end{array}\right)$ basal reflection of $\mathrm{Cl}$-sodalite; dashed line ' $\mathrm{C}$ ' is the location of the $\left(\begin{array}{lll}0 & 0 & 3\end{array}\right)$ basal reflection of $\mathrm{Cl}$-Chabazite.

\subsubsection{XRD for the FSW Sample}

In Figure 4a, the FSW sample contains original phases of raw fly ash (e.g., quartz, mullite, hematite, and magnesioferrite) that have been often observed in alkali-activated fly ash binders [11,41,42].

As reaction products, the FSW sample produced geopolymer, which manifests itself in the form of an amorphous hump at $28-35^{\circ}$ in XRD $[12,13,43]$, with several crystalline zeolite phases. At 7 days, besides geopolymeric gel, zeolite $\mathrm{Y}\left(\mathrm{Al}_{71} \mathrm{Na}_{71} \mathrm{O}_{384} \mathrm{Si}_{121}\right)$ and Cl-sodalite $\left(\mathrm{Al}_{6} \mathrm{Cl}_{2} \mathrm{Na}_{8} \mathrm{O}_{24} \mathrm{Si}_{6}\right)$ are only visible. At 28 days, while zeolite $Y$ was more synthesized, zeolite $X\left(\mathrm{Al}_{92} \mathrm{Ca}_{32} \mathrm{~K}_{28} \mathrm{O}_{384} \mathrm{Si}_{100}\right)$ and Cl-chabazite $\left(\mathrm{Al}_{2} \mathrm{Ca}_{1} \mathrm{Cl}_{2} \mathrm{O}_{8} \mathrm{Si}_{2}\right)$ are newly grown.

Zeolites $\mathrm{X}$ and $\mathrm{Y}$ are very similar zeolites that belong to faujasite. Their main difference is simply the $\mathrm{Si} / \mathrm{Al}$ ratio [44]. It is worth noting that Belviso et al. synthesized zeolites from $\mathrm{NaOH}$-activated fly ash using seawater within the temperature range of 35 to $60{ }^{\circ} \mathrm{C}$ [21]; in their study, zeolite $\mathrm{X}$ was 
observed when the samples were prepared with seawater at $35^{\circ} \mathrm{C}$, while it was not found in the samples prepared with a distilled water at the identical temperature. This result implies that zeolite $X$ is a more stable phase in seawater than in distilled water at the atmospheric temperature. Similarly, in the present study, the active formation of zeolite $X$ was observed along with zeolite $Y$. However, zeolites $\mathrm{X}$ and $\mathrm{Y}$ were not likely to contribute to the chemical Cl-binding because they contain no chlorine in their chemical compositions.

In the FSW sample, the Cl-bearing phases were Cl-chabazite and Cl-sodalite, as shown in Figure 4a. These phases are the resultant zeolites after binding the chloride. Note that geopolymeric gel resembles zeolites in terms of structure on the nanometer scale $[13,31]$, and thus the presence of Cl-chabazite and $\mathrm{Cl}$-sodalite may indicate that a portion of the geopolymeric gel in the FSW sample is very similar to them in terms of structure and composition. Therefore, these types of geopolymeric gels are likely to chemically hold a portion of the chloride in the FSW sample. However, given that the XRD peaks for zeolites $\mathrm{X}$ and $\mathrm{Y}$ are much larger than those of $\mathrm{Cl}$-chabazite and $\mathrm{Cl}$-sodalite, the zeolite $\mathrm{X}$ and $\mathrm{Y}$ types of geopolymer gel seem to have a more significant portion in the FSW sample. This may explain the limited degree of chloride binding in the FSW sample as shown in Figure 3.

\subsubsection{XRD for the SSW Sample}

Figure $4 \mathrm{~b}$ presents the XRD patterns of the SSW sample at 7 and 28 days. Here, calcium silicate hydrate I (C-S-H(I)), which is a more crystalline form of C-S-H, is found as a main reaction product $[31,45]$. Earlier studies have showed that C-S-H in concrete has the capacity to adsorb chloride ions on its surface area, referred as physical Cl-binding in hydrated portland cements [46-48]. Although the peaks of C-S-H(I) have not much grown after 7 days, C-S-H(I) would adsorb chloride to some extent.

In XRD, Cl-hydrocalumite and Cl-hydrotalcite are also identified. In hydrated portland cements, AFm phases, which belong to layered double hydroxides (LDH), play important roles in chloride chemical binding. In general, $\mathrm{Mg}, \mathrm{Ca}$, and $\mathrm{Al}$ sources in raw GGBFS lead to the formation of hydrotalcite (Mg-Al LDH) and hydrocalumite (Ca-Al LDH) in alkali-activated GGBFS [39]. Both hydrotalcite and hydrocalumite have LDH structures with interlayered anions, which can be exchanged with chloride ions $[40,49]$. In the present study, Figure $4 \mathrm{~b}$ illustrates the formation of $\mathrm{Cl}$-exchanged hydrotalcite (i.e., Cl-hydrotalcite) and Cl-exchanged hydrocalumite (i.e., Cl-hydrocalumite) in the SSW sample. Khan et al. recently found Friedel's salt as a chloride "sink" in four M-NaOH-activated GGBFS prepared with $2.47 \% \mathrm{NaCl}$ solution [22]. Although Friedel's salt and Cl-hydrocalumite are often mistaken as an identical phase [50,51], their XRD patterns [38] are not the same to each other even though these phases have a great similarity in their structures (i.e., $\mathrm{LDH}$ ); $\mathrm{Cl}$-hydrocalumite contains chloride as a dominantly interlayered anion with a small quantity of $\mathrm{OH}$ ions in its interlayer spaces, while Friedel's salt has only $\mathrm{Cl}$ ions. Due to their structural and compositional similarities, Cl-hydrocalumite may have a similar binding capability for chloride. However, as shown in Figure 5, which is the detailed XRD figure that shows the strongest peaks of $\mathrm{Cl}$-hydrotalcite and $\mathrm{Cl}$-hydrocalumite in $8^{\circ}$ to $15^{\circ} 2 \theta$ [38], only Cl-hydrotalcite seems to have significantly grown in its peak intensity from 7 to 28 days compared to Cl-hydrocalumite. Given that the bound chloride content in the SSW sample considerably increased from 7 to 28 days (Figure 3), Cl-hydrotalcite would play a more important role in binding chloride rather than $\mathrm{Cl}$-hydrocalumite in this study. 


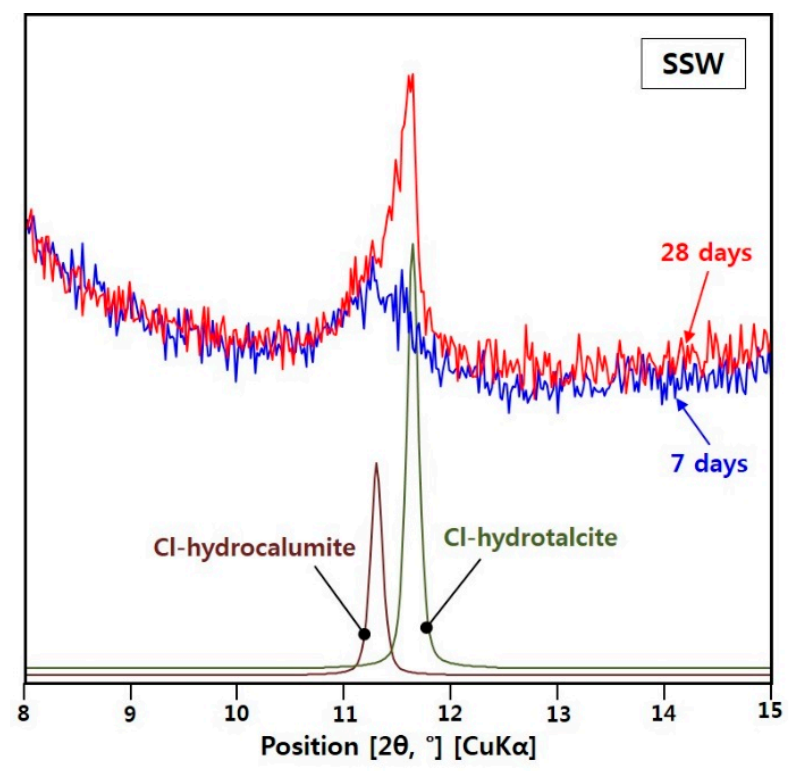

Figure 5. Detailed XRD figure of the SSW sample in $8-15^{\circ} 2 \theta$ at 7 and 28 days with reference patterns of Cl-hydrocalumite and Cl-hydrotalcite.

\subsection{MIP}

Figure 6 (see also appendix Table A1) show the MIP results of the FSW and SSW samples at 7 and 28 days.

As shown in Figure 6a, the FSW sample at 7 and 28 days has similar values of total porosity (i.e., an insignificant reduction of total porosity). However, in Figure $6 \mathrm{~b}$, the pore-size distributions display notable differences between 7 and 28 days in two size ranges: (1) 200-500 nm, and (2) below $30 \mathrm{~nm}$. Pores with sizes of 200-500 nm have decreased while pores smaller than $30 \mathrm{~nm}$ increased from 7 to 28 days. Thus, the FSW sample had a pore-size refinement.

In contrast, the SSW sample demonstrates a great reduction in total porosity from 0.08 to $0.03 \mathrm{~mL} / \mathrm{g}$, as shown in Figure 6c. The SSW sample also shows a substantial pore-size refinement (see Figure $6 \mathrm{~d}$ ). For instance, the pores larger than $0.1 \mu \mathrm{m}$ at 7 days mostly disappeared at 28 days, while the pores smaller than $0.005 \mu \mathrm{m}$ increased. The simultaneous reduction of pore size and total volume are advantageous to improve impermeability to chloride ingression.

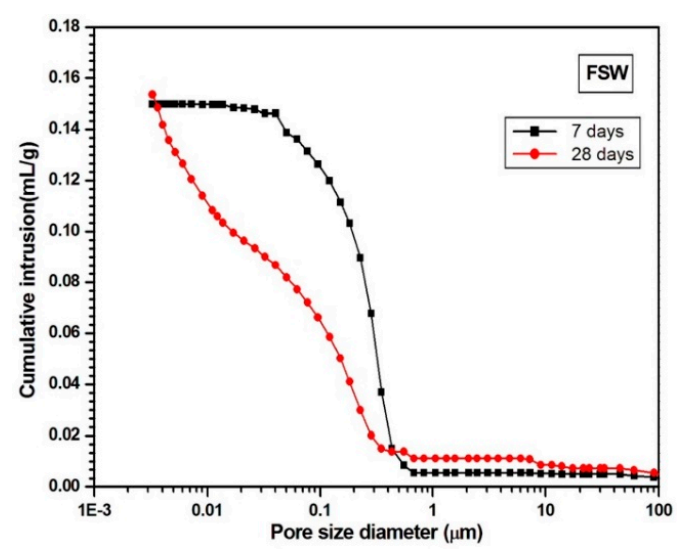

(a)

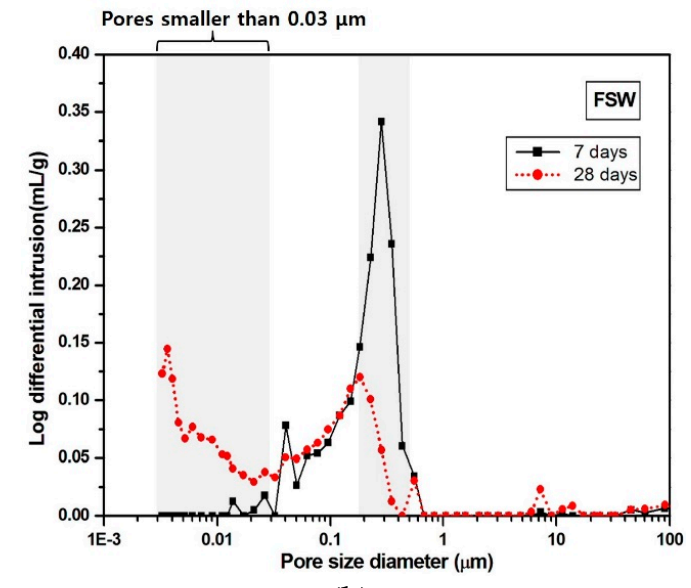

(b)

Figure 6. Cont. 


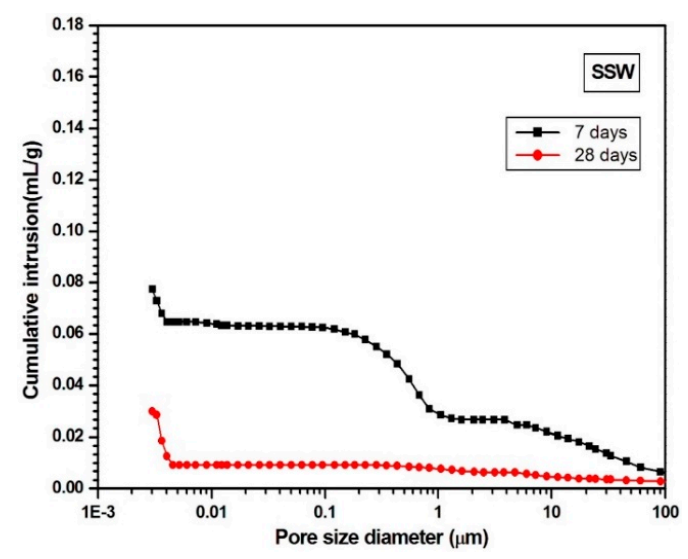

(c)

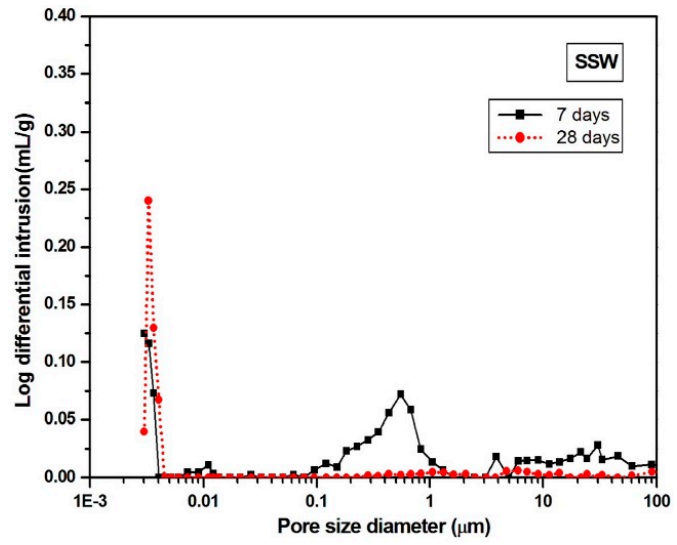

(d)

Figure 6. Pore size distribution curves of the FSW and SSW samples at 7 and 28 days: (a) cumulative distribution of the FSW sample, (b) log differential distribution of the FSW sample, (c) cumulative distribution of the SSW sample, and (d) log differential distribution of the SSW sample.

\subsection{Summary and Further Discussion}

In the present study, the alkali-activated slag system revealed a better Cl-binding capacity than the alkali-activated fly ash system after 7 days, although they had similar capacities at 7 days. In the alkali-activated slag system, Cl-hydrotalcite remarkably formed after 7 days compared to Cl-hydrocalumite, which has a similar structure with Friedel's salt. Therefore, the chemical Cl-binding mechanism in the alkali-activated slag is considerably different from the hydrated portland cement system, of which the chemical Cl-binding mostly depends on Friedel's salt.

In the alkali-activated fly ash system, the Cl-bearing zeolites did not extensively form after 7 days as much as $\mathrm{Cl}$-hydrotalcite in the alkali-activated slag system; however, zeolite $\mathrm{X}$ and $\mathrm{Y}$ were substantially synthesized after 7 days. Given that, in earlier studies $[12,13,31]$, when no $\mathrm{Cl}$ was present, dominant crystalline zeolite phases in the alkali-activated fly ash system were mostly sodalite and chabazite rather than faujasite, it is possible that the extensive formation of zeolite $\mathrm{X}$ and $\mathrm{Y}$ might suppress the formation Cl-bearing zeolites in this study, although a further study is required to understand the interactions between zeolite $\mathrm{X} / \mathrm{Y}$ and $\mathrm{Cl}$-bearing zeolites in the system.

Regarding the pore structures, the alkali-activated slag system revealed both pore-size refinement and porosity reduction after 7 days, while the alkali-activated fly ash system had only pore-size refinement. Therefore, considering $\mathrm{Cl}$-binding and pore structure, the alkali-activated slag system would have a better durability performance in seawater environments than the alkali-activated fly ash system.

\section{Conclusions}

The present study compared and discussed the chloride-binding capability, synthesized $\mathrm{Cl}$-bearing phases, and pore characteristics between alkali-activated fly ash and GGBF systems when seawater is used as the mixing water. Overall, the alkali-activated GGBFS system showed a significantly better $\mathrm{Cl}$-binding capacity than the alkali-activated fly ash system at 28 days although it demonstrated a slightly lower performance at 7 days. More detailed conclusions are given as follows:

1. The main $\mathrm{Cl}$-bearing phases were zeolites (i.e., $\mathrm{Cl}$-chabazite and $\mathrm{Cl}$-sodalite) in the $\mathrm{FSW}$ sample, while they were $\mathrm{LDH}$ phases (i.e., $\mathrm{Cl}$-hydrotalcite and $\mathrm{Cl}$-hydrocalumite) in the SSW sample.

2. The bound chloride content of the SSW sample was $91 \%$ at 28 days, whereas that of the FSW sample was $69 \%$. Therefore, at 28 days, the alkali-activated GGBFS system is more advantageous for Cl-binding than the alkali-activated fly ash system. 
3. The FSW sample contained zeolite $\mathrm{X}$, zeolite $\mathrm{Y}, \mathrm{Cl}$-chabazite, and $\mathrm{Cl}$-sodalite as crystalline zeolite phases. Zeolite $X$ and $Y$, which do not contribute to the chemical Cl-binding, comprised a larger portion of the XRD pattern than $\mathrm{Cl}$-chabazite and $\mathrm{Cl}$-hydrocalumite.

4. The SSW sample contained C-S-H(I), Cl-hydrocalumite, and Cl-hydrotalcite. Its Cl-binding mechanisms are similar to hydrated portland cement systems. C-S-H(I) is responsible for physical binding and $\mathrm{Cl}-\mathrm{LDH}$ contribute to chemical binding.

5. Between the two Cl-LDHs in the SSW sample, the XRD peak of only Cl-hydrotalcite grew significantly from 7 to 28 days, and the bound chloride content of the SSW sample considerably increased from $42 \%$ to $91 \%$ over that time. Therefore, after 7 days, Cl-hydrotalcite is an important phase for chemical Cl-binding in the alkali-activated GGBFS system.

6. The SSW sample showed both pore-size refinement and porosity reduction from 7 to 28 days. In contrast, the FSW sample only showed pore-size refinement over that time.

Acknowledgments: This research was supported by Basic Science Research Programs through the National Research Foundation of Korea (NRF) funded by the Ministry of Education (NRF- 2017R1D1A1B03034700) and also supported by the Project of Conversion by the Past R\&D Results through the Ministry of Trade, Industry and Energy (MOTIE) (N0002150, 2016).

Author Contributions: Yubin Jun designed and performed the experiments. Yubin Jun and Seyoon Yoon analyzed the data. Yubin Jun, Jae Eun Oh, and Seyoon Yoon discussed the experiment. Yubin Jun wrote the manuscript, and Seyoon Yoon and Jae Eun Oh reviewed this study.

Conflicts of Interest: The authors declare no conflict of interest.

\section{Appendix A}

Table A1. The detailed pore volumes of mercury intrusion porosimetry (MIP) results.

\begin{tabular}{|c|c|c|c|c|c|}
\hline \multirow{2}{*}{$\begin{array}{l}\text { Pore size Diameter } \\
\qquad(\mu \mathrm{m})\end{array}$} & \multicolumn{2}{|c|}{ Log Differential Intrusion (mL/g) } & \multirow{2}{*}{$\begin{array}{l}\text { Pore size Diameter } \\
\qquad(\mu \mathrm{m})\end{array}$} & \multicolumn{2}{|c|}{ Log Differential Intrusion (mL/g) } \\
\hline & FSW 7 Days & FSW 28 Days & & SSW 7 Days & SSW 28 Days \\
\hline 0.00329 & 0 & 0.12304 & 0.00303 & 0.12477 & 0.03992 \\
\hline 0.00362 & 0 & 0.14457 & 0.00329 & 0.11614 & 0.24018 \\
\hline 0.00402 & 0 & 0.11852 & 0.00362 & 0.07304 & 0.12966 \\
\hline 0.00452 & 0 & 0.0805 & 0.00402 & 0 & 0.06723 \\
\hline 0.00517 & 0 & 0.06687 & 0.00452 & 0 & 0 \\
\hline 0.00603 & 0 & 0.07686 & 0.00517 & 0 & 0 \\
\hline 0.00724 & 0 & 0.06765 & 0.00603 & 0 & 0 \\
\hline 0.00906 & 0 & 0.06558 & 0.00724 & 0.00464 & 0 \\
\hline 0.01105 & 0 & 0.05297 & 0.00906 & 0.00489 & 0 \\
\hline 0.01224 & 0 & 0.05159 & 0.01105 & 0.01095 & 0 \\
\hline 0.01373 & 0.01259 & 0.04108 & 0.01224 & 0.00332 & 0 \\
\hline 0.0171 & 0 & 0.03531 & 0.01373 & 0 & 0 \\
\hline 0.02108 & 0.00507 & 0.02946 & 0.0171 & 0 & 0 \\
\hline 0.02629 & 0.01781 & 0.03803 & 0.02108 & 0 & 0 \\
\hline 0.03239 & 0 & 0.03331 & 0.02629 & 0.0025 & 0 \\
\hline 0.04033 & 0.07809 & 0.05043 & 0.03241 & 0 & 0 \\
\hline 0.05034 & 0.02662 & 0.04926 & 0.04032 & 0 & 0 \\
\hline 0.06249 & 0.05212 & 0.05721 & 0.05035 & 0 & 0 \\
\hline 0.0771 & 0.05404 & 0.0631 & 0.0625 & 0.00274 & 0 \\
\hline 0.09539 & 0.06335 & 0.07466 & 0.07709 & 0 & 0 \\
\hline 0.12075 & 0.08667 & 0.08664 & 0.09537 & 0.00672 & 0 \\
\hline 0.15107 & 0.09919 & 0.1101 & 0.12082 & 0.01236 & 0 \\
\hline
\end{tabular}

\section{References}

1. Imbabi, M.S.; Carrigan, C.; McKenna, S. Trends and developments in green cement and concrete technology. Int. J. Sustain. Built Environ. 2012, 1, 194-216. [CrossRef]

2. Monteiro, P. Concrete: Microstructure, Properties, and Materials; McGraw-Hill Publishing: New York, NY, USA, 2006.

3. Flower, D.J.M.; Sanjayan, J.G. Green house gas emissions due to concrete manufacture. Int. J. Life Cycle Assess. 2007, 12, 282. [CrossRef]

4. Yoon, S.; Monteiro, P.J.M.; Macphee, D.E.; Glasser, F.P.; Imbabi, M.S.-E. Statistical evaluation of the mechanical properties of high-volume class F fly ash concretes. Constr. Build. Mater. 2014, 54, 432-442. [CrossRef] 
5. Mintzer, I.M. Confronting Climate Change: Risks, Implications and Responses; Cambridge University Press: Cambridge, UK, 1992.

6. Leiserowitz, A. Climate Change Risk Perception and Policy Preferences: The Role of Affect, Imagery, and Values. Clim. Chang. 2006, 77, 45-72. [CrossRef]

7. Glasser, F.P.; Marchand, J.; Samson, E. Durability of concrete-Degradation phenomena involving detrimental chemical reactions. Cem. Concr. Res. 2008, 38, 226-246. [CrossRef]

8. Winnefeld, F.; Lothenbach, B. Hydration of calcium sulfoaluminate cements-Experimental findings and thermodynamic modelling. Cem. Concr. Res. 2010, 40, 1239-1247. [CrossRef]

9. Baoying, Y.; Jun, W.; Yuxin, G.; Jiayu, X. Studies on key technology and toughness of super sulfate cement-based compound materials. Appl. Mech. Mater. 2014, 665, 151-165.

10. Fernández-Carrasco, L.; Vázquez, E. Reactions of fly ash with calcium aluminate cement and calcium sulphate. Fuel 2009, 88, 1533-1538. [CrossRef]

11. Bakharev, T. Geopolymeric materials prepared using Class F fly ash and elevated temperature curing. Cem. Concr. Res. 2005, 35, 1224-1232. [CrossRef]

12. Pacheco-Torgal, F.; Castro-Gomes, J.; Jalali, S. Alkali-activated binders: A review: Part 1. Historical background, terminology, reaction mechanisms and hydration products. Constr. Build. Mater. 2008, 22, 1305-1314. [CrossRef]

13. Provis, J.L. Alkali-activated materials. Cem. Concr. Res. 2017. [CrossRef]

14. Wegian, F.M. Effect of seawater for mixing and curing on structural concrete. IES J. Part A Civ. Struct. Eng. 2010, 3, 235-243. [CrossRef]

15. Kaushik, S.K.; Islam, S. Suitability of sea water for mixing structural concrete exposed to a marine environment. Cem. Concr. Compos. 1995, 17, 177-185. [CrossRef]

16. Roy, D.M.; Jiang, W.; Silsbee, M.R. Chloride diffusion in ordinary, blended, and alkali-activated cement pastes and its relation to other properties. Cem. Concr. Res. 2000, 30, 1879-1884. [CrossRef]

17. Fernandez-Jimenez, A.; García-Lodeiro, I.; Palomo, A. Durability of alkali-activated fly ash cementitious materials. J. Mater. Sci. 2007, 42, 3055-3065. [CrossRef]

18. Arbi, K.; Nedeljković, M.; Zuo, Y.; Ye, G. A Review on the Durability of Alkali-Activated Fly Ash/Slag Systems: Advances, Issues, and Perspectives. Ind. Eng. Chem. Res. 2016, 55, 5439-5453. [CrossRef]

19. Yoon, S.; Ha, J.; Chae, S.; Kilcoyne, D.; Jun, Y.; Oh, J.; Monteiro, P. Phase Changes of Monosulfoaluminate in $\mathrm{NaCl}$ Aqueous Solution. Materials 2016, 9, 401. [CrossRef] [PubMed]

20. De Weerdt, K.; Orsáková, D.; Geiker, M.R. The impact of sulphate and magnesium on chloride binding in Portland cement paste. Cem. Concr. Res. 2014, 65, 30-40. [CrossRef]

21. Belviso, C.; Cavalcante, F.; Fiore, S. Synthesis of zeolite from Italian coal fly ash: Differences in crystallization temperature using seawater instead of distilled water. Waste Manag. 2010, 30, 839-847. [CrossRef] [PubMed]

22. Khan, M.S.H.; Kayali, O.; Troitzsch, U. Chloride binding capacity of hydrotalcite and the competition with carbonates in ground granulated blast furnace slag concrete. Mater. Struct. 2016, 49, 4609-4619. [CrossRef]

23. Duxson, P.; Fernández-Jiménez, A.; Provis, J.L.; Lukey, G.C.; Palomo, A.; van Deventer, J.S.J. Geopolymer technology: The current state of the art. J. Mater. Sci. 2007, 42, 2917-2933. [CrossRef]

24. ASTM International. Standard Specification for Coal Fly Ash and Raw or Calcined Natural Pozzolan for Use in Concrete; Annual Book of ASTM Standards; ASTM International: West Conshohocken, PA, USA, 2008.

25. Álvarez-Ayuso, E.; Querol, X.; Plana, F.; Alastuey, A.; Moreno, N.; Izquierdo, M.; Font, O.; Moreno, T.; Diez, S.; Vázquez, E.; et al. Environmental, physical and structural characterisation of geopolymer matrixes synthesised from coal (co-)combustion fly ashes. J. Hazard. Mater. 2008, 154, 175-183. [CrossRef] [PubMed]

26. Liu, H.; Lu, H.; Chen, D.; Wang, H.; Xu, H.; Zhang, R. Preparation and properties of glass-ceramics derived from blast-furnace slag by a ceramic-sintering process. Ceram. Int. 2009, 35, 3181-3184. [CrossRef]

27. Yip, C.K.; Lukey, G.C.; van Deventer, J.S.J. The coexistence of geopolymeric gel and calcium silicate hydrate at the early stage of alkaline activation. Cem. Concr. Res. 2005, 35, 1688-1697. [CrossRef]

28. Riley, J.P.; Chester, R. Chemical Oceanography; Academic Press: Cambridge, MA, USA, 1976; Volume 6.

29. Sathonsaowaphak, A.; Chindaprasirt, P.; Pimraksa, K. Workability and strength of lignite bottom ash geopolymer mortar. J. Hazard. Mater. 2009, 168, 44-50. [CrossRef] [PubMed]

30. Jun, Y.; Oh, J.E. Use of gypsum as a preventive measure for strength deterioration during curing in class $\mathrm{F}$ fly ash geopolymer system. Materials 2015, 8, 3053-3067. [CrossRef] 
31. Oh, J.E.; Monteiro, P.J.M.; Jun, S.S.; Choi, S.; Clark, S.M. The evolution of strength and crystalline phases for alkali-activated ground blast furnace slag and fly ash-based geopolymers. Cem. Concr. Res. 2010, 40, $189-196$. [CrossRef]

32. Arya, C.; Buenfeld, N.R.; Newman, J.B. Factors influencing chloride-binding in concrete. Cem. Concr. Res. 1990, 20, 291-300. [CrossRef]

33. Cheewaket, T.; Jaturapitakkul, C.; Chalee, W. Long term performance of chloride binding capacity in fly ash concrete in a marine environment. Constr. Build. Mater. 2010, 24, 1352-1357. [CrossRef]

34. Chindaprasirt, P.; Chalee, W. Effect of sodium hydroxide concentration on chloride penetration and steel corrosion of fly ash-based geopolymer concrete under marine site. Constr. Build. Mater. 2014, 63, 303-310. [CrossRef]

35. ASTM International. Standard Test Method for Water-Soluble Chloride in Mortar and Concrete; Annual Book of ASTM Standards; ASTM International: West Conshohocken, PA, USA, 1997.

36. ASTM International. Standard Test Method for Acid-Soluble Chloride in Mortar and Concrete; Annual Book of ASTM Standards; ASTM International: West Conshohocken, PA, USA, 2008.

37. PANalytical. X'Pert HighScore Plus; PANalytical: Almelo, The Netherlands, 2012.

38. ICDD. PDF-2 Database; International Centre for Diffraction Data: Newton Square, PA, USA, 2000.

39. Haha, M.B.; Lothenbach, B.; Le Saout, G.; Winnefeld, F. Influence of slag chemistry on the hydration of alkali-activated blast-furnace slag-Part I: Effect of MgO. Cem. Concr. Res. 2011, 41, 955-963. [CrossRef]

40. Rousselot, I.; Taviot-Guého, C.; Leroux, F.; Léone, P.; Palvadeau, P.; Besse, J.-P. Insights on the Structural Chemistry of Hydrocalumite and Hydrotalcite-like Materials: Investigation of the Series $\mathrm{Ca}_{2} \mathrm{M}^{3+}(\mathrm{OH})_{6} \mathrm{Cl} \cdot 2 \mathrm{H}_{2} \mathrm{O}\left(\mathrm{M}^{3+}: \mathrm{Al}^{3+}, \mathrm{Ga}^{3+}, \mathrm{Fe}^{3+}\right.$, and $\left.\mathrm{Sc}^{3+}\right)$ by X-Ray Powder Diffraction. J. Solid State Chem. 2002, 167, 137-144. [CrossRef]

41. De Vargas, A.S.; Dal Molin, D.C.C.; Vilela, A.C.F.; Silva, F.J.D.; Pavão, B.; Veit, H. The effects of $\mathrm{Na}_{2} \mathrm{O} / \mathrm{SiO}_{2}$ molar ratio, curing temperature and age on compressive strength, morphology and microstructure of alkali-activated fly ash-based geopolymers. Cem. Concr. Compos. 2011, 33, 653-660. [CrossRef]

42. Fernández-Jiménez, A.; Palomo, A. Characterisation of fly ashes. Potential reactivity as alkaline cements Fuel 2003, 82, 2259-2265. [CrossRef]

43. Oh, J.E.; Jun, Y.; Jeong, Y.; Monteiro, P.J.M. The importance of the network-modifying element content in fly ash as a simple measure to predict its strength potential for alkali-activation. Cem. Concr. Compos. 2015, 57, 44-54. [CrossRef]

44. Bhatia, S. Zeolite Catalysts: Principles and Applications; CRC Press: Boca Raton, FL, USA, 1989.

45. Richardson, I.G.; Brough, A.R.; Groves, G.W.; Dobson, C.M. The characterization of hardened alkali-activated blast-furnace slag pastes and the nature of the calcium silicate hydrate (C-S-H) phase. Cem. Concr. Res. 1994, 24, 813-829. [CrossRef]

46. Shi, X.; Xie, N.; Fortune, K.; Gong, J. Durability of steel reinforced concrete in chloride environments: An overview. Constr. Build. Mater. 2012, 30, 125-138. [CrossRef]

47. Yuan, Q.; Shi, C.; De Schutter, G.; Audenaert, K.; Deng, D. Chloride binding of cement-based materials subjected to external chloride environment-A review. Constr. Build. Mater. 2009, 23, 1-13. [CrossRef]

48. Luping, T.; Nilsson, L.-O. Chloride binding capacity and binding isotherms of OPC pastes and mortars. Cem. Concr. Res. 1993, 23, 247-253. [CrossRef]

49. Grover, K.; Komarneni, S.; Katsuki, H. Synthetic hydrotalcite-type and hydrocalumite-type layered double hydroxides for arsenate uptake. Appl. Clay Sci. 2010, 48, 631-637. [CrossRef]

50. Kalinichev, A.G.; Kirkpatrick, R.J.; Cygan, R.T. Molecular modeling of the structure and dynamics of the interlayer and surface species of mixed-metal layered hydroxides: Chloride and water in hydrocalumite (Friedel's salt). Am. Mineral. 2000, 85, 1046-1052. [CrossRef]

51. Vieille, L.; Rousselot, I.; Leroux, F.; Besse, J.-P.; Taviot-Guého, C. Hydrocalumite and Its Polymer Derivatives. 1. Reversible Thermal Behavior of Friedel's Salt: A Direct Observation by Means of High-Temperature in Situ Powder X-ray Diffraction. Chem. Mater. 2003, 15, 4361-4368. [CrossRef]

(C) 2017 by the authors. Licensee MDPI, Basel, Switzerland. This article is an open access article distributed under the terms and conditions of the Creative Commons Attribution (CC BY) license (http://creativecommons.org/licenses/by/4.0/). 